\title{
Preschool Teacher Education in China: History, Achievements, Problems and Prospects
}

\section{Shangwei Li, Changjie Deng}

\begin{abstract}
The purpose of this paper is to sum up the pros and cons of preschool teacher education in China. Preschool teacher education has experienced a century, formed more perfect management system and internal structure, produced some useful research results, and greatly promoted the development of preschool education in China. However, Chinese preschool teacher education has still imperfect management systems and structure, and impertinent practice and research. Therefore, China should further improve ecological environment and structure, enhance the effectiveness of theory and practice in preschool teacher education and pay deeper attention to the rural preschool teacher education in the future.
\end{abstract}

Key words: preschool teacher education, preschool education, preschool children; rural, China.

\section{Introduction}

Preschool teacher education is an integral part of teacher education, which is the main method of training the preschool teachers for 0-6 years old children in China. At present, the scholars have done a lot of analysis and reflection on history, status and 
problems and put forward some useful advice. However, there are few literatures uniting history with reality, theory with practice and pre-service with in-service training in preschool teacher education. Therefore, it has important theoretical and practical meaning to further probe into the developmental history and sum up the pros and cons of preschool teacher education in China.

\section{History of preschool teacher education in China}

Preschool teacher education originated in the late $19^{\text {th }}$ century in China and has gone through 100-year history. Some scholars believed that history of preschool teacher education in China should be divided into four stages, three stages, etc. Reflecting on present research results, we believe that preschool teacher education in China has experienced the following six stages.

\subsection{Initial stage (late $19^{\text {th }}$ century -1920 s)}

During the late $19^{\text {th }}$ century and early $20^{\text {th }}$ century, with promotion of the early reformer of teacher education and advocacy of the Western Church, secondary preschool normal education system was formally established, but preschool teacher education had obvious "introduction" to foreign experiences especially Japan and had no "normal features" (Li, 2004).

About the practice and theory of the early reformers, Guan-ying Zheng in detail introduced western teacher education in his paper "School" in 1892; Qi-chao Liang systematically described his thoughts about teacher education in "On Normal Education" published in the "Times Newspaper" in 1896; Zhen-yu Luo discussed about establishment, admissions, schooling, teachers and funding of the secondary normal schools in 1901; Zhi-dong Zhang set up Hubei Kindergarten in Wuchang and invited Japanese teachers to train the preschool teachers in 1903, which meant origin of the public preschool education and preschool teacher education, and after that, there were step by step some training institutions for preschool teachers in 1905 Tianjin, 1907 Shanghai and 1916 Hangzhou; and United Kingdom-Presbyterian did the first independent secondary preschool normal school - Huai-de Preschool Normal School in Xiamen in 1912.

About legal systems of preschool teacher education, "Presented School Regulation" (1904) and "Women Normal School Regulation" (1907) meant beginning of the institutionalization of preschool teacher education in China (Chen, 2009). The former made "Meng-yang-yuan" as institution of preschool education for 3-7-year-old children; and the latter required that Women Normal School be responsible for training caretaker. At meantime, "Preschool Education Act" was published by Chinese Book Company in 1907; "Normal Education Order" and "Normal School Regulation" (1912) required that Women 
Normal School train the teachers for kindergartens and primary schools. Especially, "Renzhi-Kuichou Schooling System" (1912-1913) first divided normal education institutions into secondary and higher normal schools, and caretakers must be trained in higher women normal schools; and "Implementation Rules of National School" (1915) first provided the qualification of caretakers.

\subsection{Hard exploration (1920s - 1940s)}

In the period, many early educationists summed up the past experiences and carried out more in-depth exploration in theory and practice, and preschool teacher education had some scientific and local characteristics in modern China (Li, 2008) and opened a native "flower" (Lv, 2003).

As for theory and practice of preschool teacher education, Xing-zhi Tao set up Shanghai Institute of Preschool Education in 1925 and Nanjing Xiao-zhuang Preschool Normal School in 1929; Mo-jun Zhang set up Department of Preschool Normal Education in Jiang-shu Women Normal School in 1922; He-qin Chen presided in the journal "Preschool Education" (Nanjing) in 1927, "Curriculum Criteria for Kindergarten" in 1932 and National Preschool Normal School of Jiangxi Province in 1943; and Jia-gen Chen set up Xia-men Ji-mei Preschool Normal School in 1927.

As for management systems of preschool teacher education, "Ren-Xu Schooling System"(1922) officially set up the kindergartens with elastic courses about life for the children under six years old, and proposed to established the secondary normal school for preschool teachers; "Interim Curriculum Standards for Kindergarten" (1929, 1932, 1936) is the independent law about courses and teaching plan of preschool education; and "Normal Education Act" (1932) and "Normal Education Procedures" (1933, 1936, 1947) clearly proposed that Department of Preschool Education should be set up in Secondary Normal School, and have two or three-year preschool normal courses such as "Child Psychology", "Kindergarten Administration", "Preschool Education law" and some training about vocational morality.

\subsection{Tortuous development (1940s - 1960s)}

After the establishment of new China, China had officially formed preschool teacher education system including secondary and higher normal education, which thought much of systematic and scientific subject-instruction and "planning", and were short of "flexibility" (Huang \& Yu, 2005).

About management systems for the preschool teachers, "The decision on Reforming the Schooling System" (1951), "The Provisional Regulation of Normal School" (1952), "The Instructional Plan of Kindergarten" (1956) identified academic years (3-4 year) and courses of preschool normal school; "On Determination of Higher Normal School" (1952) 
and "Provisional Instructional Plans of Preschool Education of Department of Education in Normal College" (1956) determined the academic years and courses of higher preschool normal education; and "Instructions on Training Teachers in Primary school and Kindergarten" (1956) and "Instructional Plan of Secondary Preschool Normal School with 3-year" (1961) provided some specific requirements of training preschool teacher.

About preschool education study programs, preschool education majors were set up in Beijing Normal University and Nanjing Normal University in 1952; and there were 89 preschool normal schools and 69278 students in 1960. During 1963-1965, there were 19 secondary preschool normal schools, where mainly train preschool teachers (Chen \& Wang, 2010).

\subsection{Stagnation stage (1960s - 1970s)}

In this period, preschool teacher education in China had had a serious setback, and especially ten-year "Cultural Revolution" (1966 - 1976), been almost completely at standstill.

Since 1961, preschool education majors were gradually stopped enrollment in higher normal schools including Beijing Normal University and Nanjing Normal University. During "Cultural Revolution", all majors with preschool education in normal universities fully stopped enrollment, and only a few provinces such as Zhejiang had some trainings of preschool teacher.

\subsection{Recovery (1970s - 1990s)}

From the Third Plenary Session (1978) to the late 1990s, China actively developed preschool teacher education, secondary preschool normal schools were the main places for training the preschool teachers, and three-level system of preschool teacher education became more and more perfect.

As for management systems of preschool teacher education, "Opinions on Strengthening and Developing Teacher Education" (1978) proposed each county should set up independent secondary preschool normal school or department of preschool teacher training in secondary normal school; "Preschool Normal School Plan (draft)" (1985) further showed the uniqueness of preschool teacher training and laid the foundation for the future courses of preschool teacher education; and "Teacher Act" (1993) required that preschool teachers should graduate from secondary preschool normal schools or higher normal schools with "Children Health Care", "Children Psychology", "Introduction to Preschool Education" and "Design and Guidance of Kindergarten Activities", and should build a three-level preschool teacher education system including secondary preschool normal schools, higher normal schools and adult continuing education.

As for preschool teacher education institutions, there were 22 secondary preschool normal schools in 1979 and preschool education majors restored enrollment in higher 
normal universities such as Beijing Normal University, Nanjing Normal University, Southwest Normal University,Northwest Normal University, Northeast Normal University, etc.; Beijing Normal University started to enroll in graduate students in 1984 and Nanjing Normal University in 1986; there were 63 secondary preschool normal schools with 35,600 students in 1989; there were 17 preschool education majors in higher normal universities in 1990; the first doctoral program for the preschool education was set up in higher school in 1994; and there were about 84,300 students in secondary preschool normal schools in 1996.

\subsection{Mature stage (since the 1990s)}

Since the late 1990s, secondary preschool normal education became less and less, and preschool teacher education has gradually transferred from three-level to two-level and become more and more diverse and open.

About management systems of preschool teacher education, "Several Points on Structural Adjustment of Normal colleges" (1999) put forward diminishing the number of secondary normal schools and increasing the number of junior colleges and universities; "Regulation on Continuing Education for the Primary and Middle School Teachers" (1999) required that the initial preschool teachers should have 120-hours pre-service training and 240-hours in-service training during each five-year; "Program on the National Medium and Long-term Education Reform and Development (2010-2020)" (2010) put forward setting up the compulsory system of preschool education, generalizing preschool education and implementing "National Training Programs" of the rural preschool teachers; and "Professional Standards of Preschool Teachers (Trial)" (2011) put forward quality standards of preschool teachers and training preschool teachers.

About the internal structure of preschool teacher education, the structure of teacher education has been adjusted from three-level to second-level by means of expanding the enrollment, upgrading the levels and merging with other colleges in China since 1997. For example, Shanghai Junior College of Preschool Teachers incorporated into East China Normal University in 1997; Cheng-du Preschool Normal School and Sichuan Normal University cooperatively hold five-year preschool vocation education in 1999; Changsha Preschool Normal School changed into Changsha College for Preschool Education in 2005; and there are preschool education majors in 289 universities with bachelor degree, 45 universities with master degree and 8 universities with doctorate degree in 2014'.

\footnotetext{
1 We have mainly investigated the "Admission Brochures" of higher schools in China (Retrieved from http:// gaokao.chsi.com.cn /zyk/zybk/ schools.action? specialityld=73383291\&ssdm=)
} 


\section{Achievements of preschool teacher education in China}

From the 100-year history, China has not only made great progress and formed own characteristics, but also made achievements in practice and theory of preschool teacher education.

\subsection{Setting up the more perfect management systems}

On the one hand, China has set up the more perfect legal systems about education, which put forward basic rights and responsibilities of government, schools and teachers, and have formed macro-management system of preschool teacher education, such as "Compulsory Education Act" (1986), "Teacher Act" (1993),"Education Act" (1995) and "Higher Education Act" (1998). On the other hand, China has published a lot of management systems about preschool education, which put forward curricular and quality criteria and evaluation mechanism of preschool teacher and education, and have formed the micro-management of preschool teacher education, such as "Preschool Normal School Plan (draft)" (1985), "Statute on Kindergarten Management" (1989), "Several Opinions on Reform and Development of Preschool Education" (2010) and "Professional Standards of Preschool Teachers (Trial Implementation)" (2011).

\subsection{Forming the more reasonable structure}

On the one hand, China has formed higher-level pre-service and in-service training system of preschool teacher, and preschool teacher education has changed from threelevel (including secondary normal school, junior normal college and normal university) to two-level (including junior normal college and normal university). On the other hand, China has set up a lot of modes of preschool teacher education, which have paid more attention to uniting pre-service with in-service training, and theory with practice of preschool education. For example, the modes of pre-service training mainly include "Knowledge Mode" / "Capacity Mode" / "Emotion Mode" / "Practice Mode", and "threeyear" or "five-year" junior college / " $2+2$ " or " $3+1$ " or " $4+0$ " undergraduate programs, " $4+1$ " or " $4+2$ " master programs, and "3+3"or" $3+2$ " doctorate programs for preschool teachers, etc.; and the modes of in-service training include "Participating Training mode", "Kindergarten-based Training Mode" and "Situational Training Mode", etc.

\subsection{Promoting professional development of preschool teachers}

On the one hand, there are more and more universities with preschool education major to train the preschool teachers. For example, there are 289 universities with more 
than 24,000 bachelors each year, 45 with more than 300 masters and 8 with more than 20 doctors for preschool education in 2014 China $^{2}$. On the other hand, there are more and more preschool teachers having taken part in in-service trainings. Ministry of Education of China put forward spending five-year in training 500,000 preschool teachers from rural kindergartens and set up one kindergarten in each town since 2010, and at present have trained large number of rural preschool teachers by means of various training projects.

\subsection{Publishing a lot of research achievements}

On the one hand, China has set up a lot of research institutes of preschool education such as "Association of Chinese Preschool Education", "Institute of Preschool Education" in higher schools and "Centre of Preschool Education Research" in provinces, etc. and journals such as "Studies of Preschool Education", "Early Childhood Education", "Preschool Education", etc. which have laid solid foundation for research and academic communication for preschool teacher education. On the other hand, Chinese scholars have done their best publishing papers and works about preschool teacher education. For example, there are more than 50,000 papers about preschool teacher education published in 2014 Chinese National Knowledge Infrastructure (CNKI), which involve in history, policy, purpose, curriculum and modes about preschool teacher education; at meantime, since the 1980s, there are more than 200 works about preschool education published and usually used as the textbooks in colleges and universities such as "Preschool Education", "Curriculum Design for Kindergarten", "Evaluation of Preschool Education", "Activity Design for Kindergarten", "Research Method of Preschool Education", "Teaching for Game", "Preschool Physical or Music or Art Education", etc.

\section{Problems of preschool teacher education in China}

Reflecting theory and practice of preschool teacher education, we find that there are some problems such as imperfect managing systems and mechanism, imbalance of internal structure, low efficiency and unsatisfied research achievements in China.

\subsection{Imperfect managing systems}

Although some managing systems have been established in China, there are imperfect investment system not to meet the needs of pre-service and in-service training for

2 Information does not involve in Hong Kong, Macao and Taiwan (Retrieved from http://gaokao.chsi.com.cn/ zyk/zybk/schools. action?specialityld=73383291\&ssdm=) 
preschool teachers; unreasonable enrollment system with less number and ratio of male of college students with free normal education; imperfect teacher management mechanism where preschool teachers have little chance of training, applying for the title and increasing the income; and imperfect quality management paying more attention to result rather than process. Especially, the rural preschool teacher education lacks of enough human, material and finance, and system support and social identity, fewer students of pre-school education majors in universities are willing to roots in and commit to rural preschool education, and fewer rural preschool teachers can truly benefit from a lot of "National Training Programs", and rural kindergartens have still poor infrastructure and teaching conditions in China (Tian \& Zhou, 2009).

\subsection{Imbalance of internal structure}

There are still some imbalance in preschool teacher education such as district distribution, pre-service and in-service training, and different educational levels. For example, there are 272 universities with undergraduate program, but only 45 with master program and 8 with doctor program; and most of them are distributed in East, North and Middle China, where have more universities with preschool education and receive more undergraduate, master and doctorate students each year (see table 1).

\section{Table 1}

Number distribution of preschool education study programs at universities in 2014 China

\begin{tabular}{|c|c|c|c|c|c|c|c|c|}
\hline District & North & East & Middle & South & West-south & West-north & East-north & Total \\
\hline $\begin{array}{l}\text { Number of universities } \\
\text { and bachelors }\end{array}$ & $\begin{array}{c}45 \\
4,222\end{array}$ & $\begin{array}{c}82 \\
6,765\end{array}$ & $\begin{array}{c}41 \\
2,843\end{array}$ & $\begin{array}{c}26 \\
1,551\end{array}$ & $\begin{array}{c}45 \\
3,348\end{array}$ & $\begin{array}{c}28 \\
3,693\end{array}$ & $\begin{array}{c}22 \\
2,456\end{array}$ & $\begin{array}{c}289 \\
24,878\end{array}$ \\
\hline $\begin{array}{l}\text { Number of universities } \\
\text { and masters }\end{array}$ & $\begin{array}{c}6 \\
33\end{array}$ & $\begin{array}{c}14 \\
137\end{array}$ & $\begin{array}{c}4 \\
30\end{array}$ & $\begin{array}{c}4 \\
27\end{array}$ & $\begin{array}{c}4 \\
58\end{array}$ & $\begin{array}{c}4 \\
19\end{array}$ & $\begin{array}{c}7 \\
41\end{array}$ & $\begin{array}{c}45 \\
345\end{array}$ \\
\hline $\begin{array}{l}\text { Number of universities } \\
\text { and doctors }\end{array}$ & $\begin{array}{l}1 \\
4\end{array}$ & $\begin{array}{c}3 \\
11\end{array}$ & $\begin{array}{l}1 \\
4\end{array}$ & $\begin{array}{l}0 \\
0\end{array}$ & $\begin{array}{l}2 \\
3\end{array}$ & $\begin{array}{l}0 \\
0\end{array}$ & $\begin{array}{l}1 \\
4\end{array}$ & $\begin{array}{c}8 \\
26\end{array}$ \\
\hline \multicolumn{9}{|c|}{$\begin{array}{l}\text { Explanation: } \\
\text { 1. Information does not include Hong Kong, and Macao and Taiwan in South China. } \\
\text { 2. Number of bachelors or master or doctor is "mean" because some universities enroll in college students not according to major } \\
\text { of education but discipline. }\end{array}$} \\
\hline
\end{tabular}

In addition, there is no independent teacher education system for rural preschool children and education; and the preschool teachers in rural areas have little chance receiving continuing education and full-time learning, and their diplomas lack of pertinence in rural preschool education (Tian \& Zhou, 2009). 


\subsection{Low-efficiency of preschool teacher education}

On the one hand, Chinese higher schools not only train limited undergraduate, master and doctor students for preschool education each year but also they are imbalance in district distribution (see table 2); and some in-service trainings usually short of pertinence due to "formalism", "utilitarianism" and "pragmatism" orientation.

Table 2

Ratio distribution of universities per province and college students per university of preschool education study programs in universities in 2014 China

\begin{tabular}{|l|c|c|c|c|c|c|c|c|}
\hline District & North & East & Middle & South & West-south & West-north & East-north & Mean \\
\hline $\begin{array}{l}\text { Ratio of universities } \\
\text { and Provinces }\end{array}$ & 9.0 & 11.7 & 13.7 & 8.7 & 9.0 & 5.6 & 7.3 & 9.3 \\
\hline $\begin{array}{l}\text { Ratio of bachelors } \\
\text { and universities }\end{array}$ & 93.8 & 82.5 & 69.3 & 59.7 & 74.4 & 131.9 & 111.6 & 86.1 \\
\hline $\begin{array}{l}\text { Ratio of masters } \\
\text { and universities }\end{array}$ & 5.5 & 9.8 & 7.5 & 6.8 & 14.5 & 4.8 & 5.9 & 7.7 \\
\hline $\begin{array}{l}\text { Ratio of doctors } \\
\text { and universities }\end{array}$ & 4.0 & 3.7 & 4.0 & 0 & 1.5 & 0 & 4 & 3.3 \\
\hline $\begin{array}{l}\text { Explanation: } \\
\text { 1. Information does not involve in Hong Kong, and Macao and Taiwan in South China. } \\
\text { 2. Number of bachelors or master or doctor is "mean" because some universities enroll in college students not according to major } \\
\text { of education but discipline. }\end{array}$ \\
\hline
\end{tabular}

(Retrieved from http://gaokao.chsi.com.cn/zyk/zybk/schools.action?specialityld=73383291\&ssdm=)

On the other hand, the simple purpose pays more attention to training "subject expert", the simple curricula lack of "teacher education" or "normal" features and rural pertinence, the methods and modes are simple, and valuation is "utilitarian" (Chen \& Wang, 2010); and pre-service trainings pay more attention to educational theory than practical skills and abilities (Wang, 2012), on the contrary, in-service trainings pay more attention to teaching skills and abilities than educational ideas and practical wits and some are repeated and "formalism" (Guo, 2012).

\subsection{Dissatisfied research achievements}

As for research about preschool teacher education, the scholars seem to think much of applied research such as investigation and pay little attention to theoretical innovation; pay more attention to in-service training than pre-service training and more attention to urban preschool teachers than rural ones. For example, as for works about 
"preschool education", few discussed "preschool teacher education", and there is no systematical textbook on how to train preschool teacher in higher schools; as to the present literatures about "modes of preschool teacher modes" in CNKI, the scholars thought much of investigation and experience summary on "in-service training of rural preschool teacher", and paid little attention to "pre-service training of rural preschool teacher" and "integration of pre-service and in-service training", and especially had no deep analysis on "essence", "basic factors", "theoretical basis" and "influencing factors or causes" of rural preschool teacher education.

\section{Prospects of preschool teacher education in China}

Facing up to the problems of preschool teacher education, we consider that it is imperative to improve ecological environment and structural system, and enhance pertinence and effectiveness of practice and research quality of preschool teacher education in future China.

\subsection{Improving the ecological environment}

From 1978 to now, Chinese government has invested considerable human, material and financial resources in preschool teacher education, but due to some historical reasons and practical factors, managing system and mechanism of preschool teacher education are still imperfect, there are poor infrastructure and teaching condition in some higher schools and rural kindergartens, the preschool teachers in rural areas are facing up to low income, poor living condition and less chance of training. Thus, it is very necessary to further increase the investment in human, material and financial resources, improve infrastructure and teaching condition of pre-service training and in-service training and the living environment of the rural preschool teachers, and build new investment system of combination with a public financial support, community and family involvement (Shi, Jiang \& Hong, 2013).

\subsection{Improving the structural system}

Although China has established more perfect structural system, it cannot still meet the needs of development of preschool children and preschool education because of fewer universities with preschool education study programs and the imbalance in distribution and levels of preschool teacher education. Investigation shows that there are at least 228 higher schools with early childhood education and four-level degrees including 210 universities with undergraduate programs, 162 with master programs, 
78 with doctor programs and 33 with specialists in America ( $L i, 2015)$. Therefore, it is necessary to promote the integration of pre-service and in-service training for the preschool teacher, adjust the district distribution of preschool teacher education in higher schools and especially increase the enrollments in free preschool normal education to train more and more rural preschool teachers in West China, and strengthen graduate education including master, specialist and doctor of preschool education in Chinese higher schools.

\subsection{Enhancing practical pertinence}

Besides improving management and structural systems, China should further set up more reasonable purposes, curricula, modes and evaluation in order to enhance the pertinence and efficiency of preschool teacher education. On the one hand, pre-service training for preschool teacher should think much of learning and reflective abilities and application of information technology, the core purpose should promote children development; general or common curricula involved in both arts and sciences mainly be selective; professional curricula research children; and educational practice be wide, dispersed, long-term and back and forth with theoretical learning (Fang, 2011). On the other hand, the in-service trainings for the rural preschool teachers should pay close attention to rural life, widely absorb native resources, make high-quality kindergarten fully play leading role; and develop their professional autonomy, professional ethics and professional wisdom and enhance their subjective consciousness and autonomy of the professional development by means of action research, instructional reform and reflection.

\subsection{Enhancing the efficiency of research achievements}

As for preschool teacher education, papers and works published are at present main forms of research achievements. On the one hand, China should enhance the quality of research achievements. In fact, China need producing a set of systematic and highquality teaching materials and publishing a series of achievements for pre-service and in-service training of preschool teachers in higher schools. On the other hand, China should further strengthen poor research fields. Chinese scholars should pay more attention to connotation/factors/theoretical foundation/ evaluation mechanism, further sum up and develop practical experiences, and deeply research issues of rural preschool teacher education. 


\section{Conclusion}

In conclusion, Chinese preschool teacher education has gone through 100 years and built up a lot of experiences in management system, internal structure, practical modes and research achievements. It has not only played a great role in training preschool teachers, but also made great contribution to healthful and balanced development of rural and urban preschool education in China.

At meantime, it will be very necessary to improve ecological environment, adjust internal structure, enhance quality of educational practice and research achievements of preschool teacher education and give deeper concern rural preschool teacher education in future China.

\section{Acknowledgement}

This research is supported in funding by China Scholarship Council and Association of Philosophy and Social Science of Sichuan Province in PRC and we would like to say "thanks" to them.

\section{References}

Chen, J. F. (2009). On historical development of preschool teacher education in modern China [Unpublished Master Dissertation]. Fujian Normal University, PRC.

Chen, Y. \& Wang, C. Y. (2010). 60-year history and prospect of kindergarten teacher education in China. Early Childhood Education (Educational Science), (6): 6-11.

Fang, J. J. (2011). On the characteristics of pre-service training courses for pre-school teachers in developed countries. Elementary \& Secondary Schooling Abroad, (5): 37-39.

Guo, Z. L. (2012). Investigation on professional development and living condition of private preschool teacher in Henan Province. Journal of Inner Mongolia Normal University(Educational Science), (8): 75-78.

Huang, Q. \& Yu, H. M. (2005). Modern four-times wave of preschool education learning from the other countries in China. Forum on Contemporary Education, (6): 42-43.

Li, L. (2004). Reflection on 100-year development of preschool teacher education. Early Childhood Education, (2): 16-17.

$\mathrm{Li}$, Z. C. (2008). Historical evolution of the preschool normal education in modern China.Studies in Preschool Education, (11): 41-44.

Li, S. W. (2016). Development and reflection on early childhood education in USA higher schools. E-Pedagogium, (2).

Lv, P. (2003). On history of the preschool education reform in China: Some recognition the Chinese preschool education movement during 1920s-1930s. Studies in Preschool Education, (5): 40-42.

Shi, L., Jiang, Y. \& Hong, X. M. (2013). Analysis on feasibility, implementation and effectiveness of present policy of the preschool teachers. Studies in Early Childhood Education, (5): 28-33. 
Tian, J. Z. \& Zhou, D. Y. (2009). Investigation on continuing education of the rural preschool teachers in Hunan Province.Teacher Education Research, (4): 66-70.

Wang, F. (2009). Main trend and issues of reform of preschool teacher education in China.Studies in Preschool Education, (6): 16-19.

Wang, Y. L. (2012). The status quo and improvement of undergraduate practical courses for preschool education. Studies in Early Childhood Education, (11): 53-55.

\section{Contact:}

Mgr. Shangwei Li

Institute of Rural Preschool Education, Yibin University

Yibin, PRC, 644007

Ph.D. Student, Institute of Special Education Studies, Palacký University in Olomouc

Žižkovo nám. 5, 77140 Olomouc, Czech Republic

E-mail: 1967shangwei@163.com

Changjie Deng

Faculty of Education, South-West University

Chongqing, PRC, 400715

E-mail: 1280301722@qq.com) 